\title{
バイオマス半炭化の原理と効用
}

\section{Principle of Semi-carbonization of Biomass and the Effect on Use}

\author{
佐野 寛 ${ }^{*}$ - 本庄 孝子** \\ Hiroshi SANO and Takako HONJO
}

Key Words: Biomass, Semi-carbonization, Energy Yield, Energy Density

\section{1.はじめに}

バイオマス資源の中で、木質は最も豊富に存在しており、 古くから薪や柴はエネルギー利用の主役であった。だが 20 世紀に入って、化石燃料が急激に台頭した結果、燃料の王 座から転落した。それは、資源量確保が不満足なだけでな く熱量密度が低く、輸送・貯蔵性が化石燃料に比べて大幅 に劣っているためである。特に実用的に最も重要な体積密 度において、固体然料では空隙率が高くなるために、石油 系に比べて著しく劣る（Table 1）ことが問題である。

半炭化物は、2000 年代初頭に産総研の環境化学技術研究 部門において、バイオマスの高エネルギー密度化手法の一 つとして提唱されたもので ${ }^{1)}$ 、基本的には加熱・加圧によっ て脱水と空隙率の減少をはかるものである。その背景とし ては、従来法による炭化、すなわち完全な脱水分解を行う 木炭化では、エネルギー収率が低下すると同時に、圧密化 が困難になるという問題があったのである。

\section{2. 半炭化の定義}

平均的な木質の化学組成は、 $\left(\mathrm{CH}_{0.2} \cdot 0.66\left[\mathrm{H}_{2} \mathrm{O}\right]\right) \mathrm{n}$ である。 したがって、完全に脱水（=-0.66 $\left.\left[\mathrm{H}_{2} \mathrm{O}\right]\right)$ することができ

Table 1 Heating value per weight or volume

\begin{tabular}{|l|l|r|}
\hline & $\mathrm{MJ} / \mathrm{kg}$ & \multicolumn{1}{|c|}{$\mathrm{MJ} / \mathrm{L}$} \\
\hline 木質 (乾物) & 20 & $10 \pm 2$ \\
樹皮 (乾物) & 18 & $9 \pm 2$ \\
生木 (水分 45\%) & 10 & $5 \pm 1$ \\
木炭 & $30 \pm 2$ & $12 \pm 2$ \\
\hline 石炭 (一般炭) & $24 \sim 27$ & $16 \sim 20$ \\
コークス & $26 \sim 31$ & $17 \sim 20$ \\
\hline 灯油 & 44 & 37 \\
C 重油 & 40 & 39 \\
\hline
\end{tabular}

れば、理想的にはほとんど炭素が残り、重量が半減してエ ネルギーをほとんど温存した炭が得られるものと期待され る。ところが実際に加熱すると、水蒸気以外にガスやター

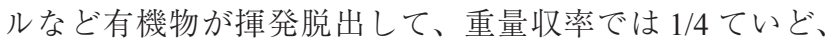
エネルギー収率としても1/2くらいにしかならない。

木質の空気を絶った加熱処理（乾留）では、その重量変 化は、Fig.1の熱分解曲線(乾留曲線)のような経過をたどる。 ここで横軸は加熱温度、縦軸は残存した固体 (残留炭素分) の原木 (絶乾物) に対する重量％を採る。残炭分の低下は $250^{\circ} \mathrm{C}$ 付近でもっとも急激に起こり、さらに $400^{\circ} \mathrm{C}$ 以上でも ゆっくり低下が続き、最終的には $1 / 3 \sim 1 / 4$ くらいの重量 の炭化物 (木炭) が得られる。

加熱分解の前半では、およそ $2 / 3$ (絶乾物比) の化学結 合水が脱離する。同時に、かなりの有機物も分解・揮発し、 残炭分の含有エネルギー低下を招いている。

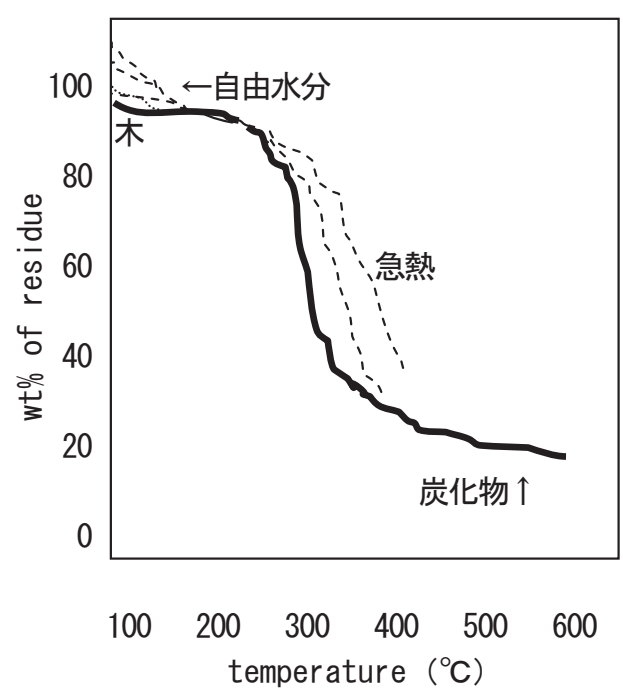

Fig.1 Thermal decomposition yield of woody material

*地球エネルギーシステム研究所（干 562-0004 大阪府箕面市牧落 5-8-2-106）

Laboratory of Global Energy System (5-8-2-106 5-8-2-106 Makiochi, Minoh, Osaka, 562-0004 Japan)

**阪南大学 (** $\overline{\mathrm{T}}$ 563-0022 大阪府池田市旭丘 2-14-20)

Hannan University (2-14-20 Asahigaoka, Ikeda, Osaka, 563-0022 Japan) 
後半の緩やかな重量減少は、主に熱分解により有機分子 が分裂して揮発する過程である。揮発する有機物がほとん ど飛んだ残留物は、木炭と呼ばれ、揮発分がそしいために 火炎を上げて燃えることがなく、穏やかに「炭火燃焼」す る燃料となる。

そこで、この炭化を途中で打ち切り、燃焼に寄与しない 水分をできるだけ除去し、しかも可燃分だけを製品に確保 しょうとするのが「半炭化」である。

乾留曲線は、加熱方法によってかなり変動する。たとえ ば、急速加熱すると、脱水や分解が昇温に追いつかず、曲 線は右方へ移動する (Fig.1の中央の点線)。その場合、揮 発成分がすぐに除去されると、二次的な炭化・縮合が起己 らないので炭化物の収率は低下し、代わりに木タールなど が増収できる。最近は木質液化法の一つとしても研究され ている。本稿は半炭化物が目的なので、液化については省 略する。

半炭化物とは、Fig.1の乾留曲線の、炭化物に到らない $\mathrm{S}$ 字部分の前後から得るもの、と考えてよい。

\section{3. いろいろな半炭化物がある}

木質の炭化を、S 字型炭化曲線に沿って昇温する途上、 その取り出し位置によってさまざまな「半炭化物」が得ら れる。そこで原料木から出発して、加熱に伴う変化を追っ てみる (Fig.2)。

原料木質は、一般に多量の水分を含んでいる。生木の多 くは $40 \sim 60 \%$ の水分を含み、野積みされた風乾物でも 20 〜 30\%の水分が普通である。長期の屋内乾燥ないし温風乾 燥したものでようやく $10 \sim 15 \%$ になる。Fig.2 の左上部に おいて、点線で表示されている不定部分は、原料含水分の 多少による変動に相当する。

自由水分は水の沸点 $100^{\circ} \mathrm{C}$ において急激に蒸発し、昇温 速度や通気条件にもよるが、 $120^{\circ} \mathrm{C}$ 付近までに大部分が揮発 する。

乾燥が終り、昇温しても重量変化の乏しい平坦な部分が あり、これらは「くん材」と呼ばれる。化学的な組成は木 質から変化していないが、木材質が引き締まり、物性にも 多少の変化が起きる。

加熱を続けて現れる急激な重量変化を表す $\mathrm{S}$ 字曲線の前 後が「半炭化域」である。昔から、この $280 \sim 380^{\circ} \mathrm{C}$ 域の 焼成物は半焼け炭と呼ばれ、失敗した炭焼き産物とみなさ れていた。今回はそれをエネルギー収率向上・エネルギー 密度向上の鍵として取り上げる。

「半炭化域」は化学性や物理性において大きく変動する領 域を含むので 3 区分して整理する。 $\mathrm{S}$ 字曲線の肩の部分、 $\mathrm{S}$ 字曲線の中点付近、 $\mathrm{S}$ 字曲線の出口（重量急減少が終りゆ るやかな減少直線に入る部分)、とに仕分けし、それぞれ半 炭化物 I 、II、II と分類する。

半炭化物 I、II、III 、収量・組成・発熱量いずれも大

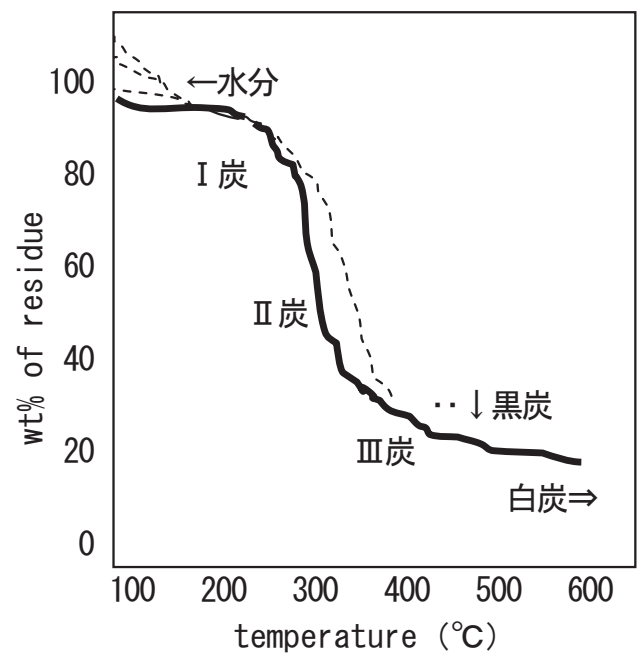

Fig.2 Various semi-carbonized charcoal

Table 2 Three types of semi-carbonized charcoal

\begin{tabular}{|c|c|c|c|}
\hline 半炭化物 & 化学組成 & 重量収率 & エネ収率 \\
\hline I & 木質なみ & $100 \sim 90 \%$ & $100 \sim 95 \%$ \\
II & $2 / 3$ 脱水 & $80 \sim 50 \%$ & $90 \sim 75 \%$ \\
III & $4 / 5$ 脱水 & $50 \sim 40 \%$ & $75 \sim 70 \%$ \\
\hline (木炭 $)$ & $9 / 10$ 脱水 & $25 \pm 10 \%$ & 約 $40 \%$ \\
\hline
\end{tabular}

きく異なり、それにつれて物性も、期待用途もまた変移す る。Table 2 に、その概要を示す。輸送・貯蔵の見地からは、 エネルギー収率は高い方がよく、重量収率は低い方が好ま しい(エネルギー密度が上昇するため)。

化学組成 $\left(\mathrm{CH}_{0.2} \cdot 0.66\left[\mathrm{H}_{2} \mathrm{O}\right]\right) \mathrm{n}$ として組み込まれている 化合水を加熱して完全に脱水しようとすると、燃料である 有機物も同時に徐々に熱分解揮発するので、Table 2 の最 下欄にある木炭のように、エネルギー収率が大幅に低下す ることは避けられない。

\section{4. 木質の構成成分ごとの熱分解曲線}

木質の主成分はセルロースであり、副成分としてへミセ ルロース、リグニンがある。これらは植物種ごとに少しづ つ異なるが、おおまかには、 $2: 1: 1$ の比率で含まれている。 化学的反応性はかなり異なるので、その熱分解曲線もまた 異なっている。

木質熱分解曲線は基本的に、この 3 者の熱分解曲線の「合 成」で表現されると見てよい。そこで、三成分それぞれの 熱分解挙動について検討する。

4.1 セルロース

分子式は $\left(\mathrm{C}_{6} \mathrm{H}_{10} \mathrm{O}_{5}\right) \mathrm{n}$ 、あるいは水分子を外へ書き分けて、 $\left(6 \mathrm{C} \cdot 5\left[\mathrm{H}_{2} \mathrm{O}\right]\right) \mathrm{n}$ 、である。グルコース単位 $\left(\mathrm{C}_{6} \mathrm{H}_{10} \mathrm{O}_{5}\right.$, Fig.4, 


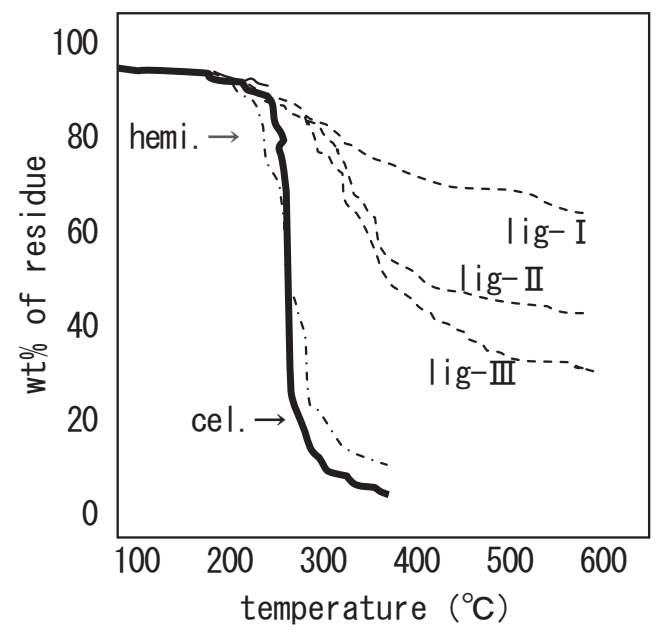

Fig.3 Thermal decomposition Curve of Cellulose (cel), Hemicellulose (hemi), and Lignin (lig)

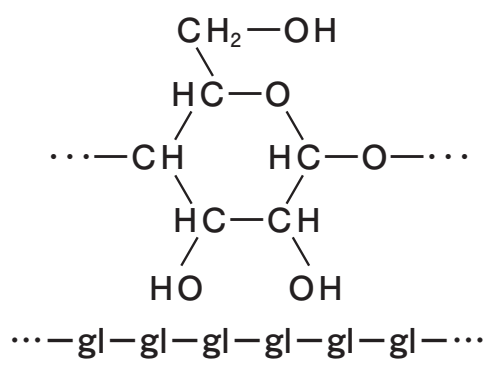

Fig.4 Glucose unit $\left(\mathrm{C}_{6} \mathrm{H}_{10} \mathrm{O}_{5}\right)$ and the chain

$\mathrm{gl}$ と略す) が 1 万個ほどつながって直線状のセルロース（繊 維素）を構成している。

グルコース単位（gl）には 3 個の $\mathrm{OH}$ 基があり、それは 水分子と水素結合で架橋しやすく、水を吸着すると最大で $\left(\left[\mathrm{C}_{6} \mathrm{H}_{10} \mathrm{O}_{5}\right] \cdot 3 \mathrm{H}_{2} \mathrm{O}\right)$ 組成となり、それは約 $22 \%$ の吸湿セルロー スに相当する。

セルロースの $\mathrm{OH}$ 基はほぼ平面に拡がっていて、吸湿水 がない場合には直接、他のセルロース直鎖分子の $\mathrm{OH}$ 基と の間に水素結合で架橋し、強勒な䋊維を形成している。

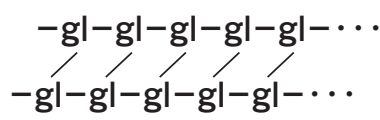

したがって、セルロースを $22 \%$ 以下の水分へ乾燥するほ ど $\mathrm{OH}$ 基が解放され、直鎖分子間の架橋に使われるように なり、強勒性を増すことが理解される。

セルロースの純品を熱分解すると、 $240^{\circ} \mathrm{C}$ 付近で直鎖分子 が切れて、一斉に揮発する。Fig.3 の中央の直立した熱分解 曲線がそれである。セルロースの切れ方は、グルコース単 位ごとに切れて内部エーテル化（分子内で C-O-C 結合を形 成）したレボグルコサン（Fig.5、グルコースの持つ $\mathrm{OH}$ 基<smiles>OC1C2COC(O2)C(O)C1O</smiles>

Fig.5 Levoglucosan

同士が脱水縮合した、 $109^{\circ} \mathrm{C}$ の融点を持つタール状物質）や、 その他の低分子断片（酢酸、メタノール、等）の生成であっ て、それらはすぐ揮発し、減量につながる。レボグルコサ ンは木タールの構成成分にもなるが不安定な物質で、加熱 滞在時間が長引けば断片化してガス化するか、重合して炭 化するかして、消失する。

4.2 ヘミセルロース

ヘミセルロースは、グルコースと他の単糖類（マンノー ス、キシロースなど）が縮合してセルロースと似た長鎖分 子となったものの混合物であり、単一物質ではない。半繊 維素という呼称もある。

グルコースとキシロースとの交互・縮合物であるグルコ キシランの分子式は $\left(\mathrm{C}_{6} \mathrm{H}_{10} \mathrm{O}_{5} \cdot \mathrm{C}_{5} \mathrm{H}_{8} \mathrm{O}_{4}\right) \mathrm{n}$ 、あるいは、(11C・ $\left.9\left[\mathrm{H}_{2} \mathrm{O}\right]\right) \mathrm{n}$ である。基本的にセルロースとよく似た $\mathrm{OH}$ 基を 持ち、同様な吸湿性や、分子鎖の会合性を持っている。だが、 分子鎖がセルロースほど対称性がよくないので、結晶性が 劣り、繊維としても脆弱である。キシロース単位を xy と書 くと、グルコキシランの形は次のような線状分子になって いる。

\section{$-g|-x y-g|-x y-g \mid-\cdots$}

ヘミセルロースは常に混合物なので、熱分解曲線もセル ロースのようにシャープな熱分解点を示さない。熱分解急 変点を含む $\mathrm{S}$ 字曲線も温度巾が拡がり、なだらかになる。

熱水やアルカリ水の存在で容易に加水分解してグルコー スや他の単糖になる。僅かな水や水蒸気の共存で加熱する と、熱分解温度 $\left(>240^{\circ} \mathrm{C}\right)$ に到る前に、 $140 \sim 180^{\circ} \mathrm{C} て い$ どの加熱で既に崩壊・軟化が始まる ${ }^{2)}$ のがへミセルロース の特色である。加熱・軟化した木質からは、実際にマンノー スやキシロースなどを水抽出することができる。

ヘミセルロースは、純品を得ることができないので、そ の単品の熱分解曲線を描くことができない。Fig.3に描い たモデル熱分解曲線は、セルロースなどと共存した熱分解 曲線から推定した曲線である。

天然のヘミセルロースはセルロースの約半量程度、同伴 して存在するのが普通なので、分離するには、アルカリ水 溶液で煮沸してへミセルロースを溶解除去する。だが溶出 物は、へミセルロースではなく分解生成した糖類であり、 
ヘミセルロースの純品が得られるわけではない。

4.3 平均的リグニン

リグニンもまた、各種の混合物である。平均的組成は $\left(\mathrm{CH}_{0.8} \cdot 0.3\left[\mathrm{H}_{2} \mathrm{O}\right]\right) \mathrm{n}$ であるが、かなりの組成巾がある。芳 香族環状化合物の部分と、C-C 側鎖の脂肪族部分とから成 る。側鎖部分の大きさは通常、芳香族部分の $1 / 3 \sim 1 / 2$ (炭 素数として）である。

\section{芳香核 $-\mathrm{C}-\mathrm{C}-\mathrm{C}-($ 側鎖 $)$}

リグニンはセルロースなど炭水化物（基本的に $\mathrm{C} \cdot \mathrm{n}\left[\mathrm{H}_{2} \mathrm{O}\right]$ 組成）と異なり、線状高分子ではなく、芳香核が側鎖など で複雑につながった三次元高分子である。硬くて脆く、植 物では骨格構造を形成している。親水性に乏しく、セルロー ス表面を覆って化学反応から守る機能もあるので「リグノ セルロース」と呼称されることがあるが、セルロースと化 合しているわけではない。

その側鎖、脂肪族部分はセルロースやへミセルロース同 様に $200^{\circ} \mathrm{C}$ 過ぎで分解が始まるが、芳香族部分は熱安定性 が高く、加熱を進めると重合・炭化へ進みやすい。

芳香族部分には、 3 種の型がある。グアヤシル基（G 型）、 シリンギル基（ $\mathrm{S}$ 型）、ヒドロキシフェニル基（H 型）であ る。Fig.6に、その基本形を示す。

$\mathrm{OH}$ 基の隣接位が最も反応性が高い活性点なので、そこ が $\mathrm{RO}$ 基（ $\mathrm{R}$ はメチル基が多い）によって塞がると、その リグニンの反応活性は低下する。その結果、重合・炭化活 性も変化する。活性の高い順は、

$$
\mathrm{H} \text { 型 }>\mathrm{G} \text { 型 }>\mathrm{S} \text { 型 }
$$

であって、加熱炭化の起こりやすさもほぼこの活性順に なる。

樹種によって、どの型のリグニンが多いかは、およそ決 まっている (Table 3)。針葉樹はリグニン含有量が 25 $30 \%$ と比較的高く、炭化しやすいと見なされているが、そ れだけではなく重合しやすい $\mathrm{G}$ 型リグニンに富んでいるた めでもある。

また、広葉樹が高温において焼きしまりができ、高密度 の備長炭（白炭）などを生成できる理由の 1 つは、高温ま で温存されている $\mathrm{S}$ 型リグニンを多く含むためといえる。

リグニンの熱分解曲線は、単一ではなくFig.3における 右側に示されるモデル曲線群に分れる。活性が高く縮合し やすい $\mathrm{H}$ 型リグニンの場合、分解揮発するのは側鎖部分た けで、芳香核はほとんど炭化物として固定される（Lig- I ） であろう。G 型リグニンでは、2/3 以上が炭化物になる（ligII )。芳香核の一部分は縮合する前に高温で分解揮発してグ アヤコールなど木タールを発生する。 $\mathrm{S}$ 型リグニンの炭化 重合は遅く、炭化収量は半分くらいになる（lig- III）。

リグニンの熱分解開始温度は、文献によって $300^{\circ} \mathrm{C} 、$
$(\mathrm{H}$ 型 $) \mathrm{HO} \longrightarrow \mathrm{C}-\mathrm{C}-\mathrm{C}-$
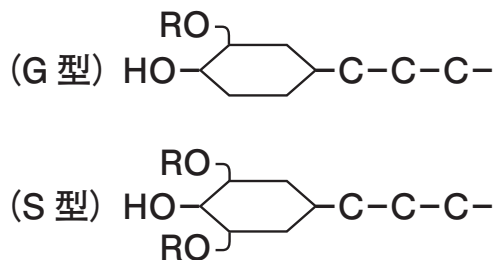

Fig.6 Typical lignin-units

Table 3 Plant vs. the Types of lignin

\begin{tabular}{|ccc|l|}
\hline 植 & 物 & 種 & リグニンの芳香族型 \\
\hline 針 & 葉 & 樹 & $\mathrm{G}$ 型リグニン \\
\hline 広 & 葉 & 樹 & $\mathrm{G}$ 型リグニン $+\mathrm{S}$ 型リグニン \\
\hline イネ科植物 & $\begin{array}{l}\mathrm{G} \text { 型リグニン } \\
+\mathrm{H}\end{array}$ 型リグリグニン \\
\hline
\end{tabular}

$340^{\circ} \mathrm{C} 、 420^{\circ} \mathrm{C}$ なととばらばらな值が出ているが、それはリ グニン本体の熱分解温度ではなく、C-C 側鎖の分解温度 $(350$ $\pm 100^{\circ} \mathrm{C} ）$ を示すものと考えられる。

リグニン試薬の信頼性

リグニン抽出分離には今のところ完全な成功例はない。 セルロースやへミセルロースを強酸などによって溶解させ て、残留物としてリグニンを得る方法では、リグニンの変 質は避けられない。また、セルロースを温存してリグニ ンを溶解させる亜硫酸パルプ法や、リグニンを酸化溶解さ せる方法では、溶解したリグニンにはスルホン基が付加さ れていたり、酸化崩壊していたりして、リグニンとは別な 物質が回収される。比較的変質の少ない方法に、トルエン やジオキサンなど有機溶媒で稳やかに抽出する方法がある が、リグニン収率が低く、リグニン全体の中の低分子部分 だけを抽出しているものと考えられる。

\section{4 木質の熱分解曲線の合成}

それは、セルロースを主体として、へミセルロース及び リグニンの各種モデル物質の熱分解曲線を合成したものと 考えられるので、へミセルロースの種類、リグニンの種類 の組み合わせによって、さまざまな熱分解曲線が現れる。 しかし、セルロース以外は、真正のモデル物質を得ること ができていないので、これらの曲線は現実を解釈し推論す るための作業仮説用として利用するほうがよい。

\section{5. 半炭化物各種}

昔は森林資源として薪と木炭が、燃料の王者であった。 しかし、厨房燃焼器のカマドは、不衛生・低伝熱効率（10 


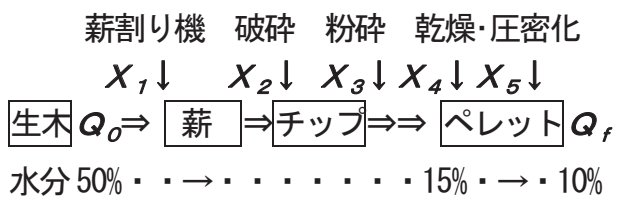

Fig.7 Energy balance for woody biomass on the production process

〜 20\%）なので LP ガス・天然ガスに代り、暖房も薪ストー ブから灯油ストーブに代わり、さらに大規模炉や熱機関は 重油や石炭に替った。21 世紀に入り石油生産がピークを越 した気配となり、木質燃料の復活が始まった。しかし燃焼 制御の容易さが要求され、薪の復活ではなく、大勢はチッ プとペレットへ向かっている。その流れの中で、半炭化物 はどの位置にくるであろうか。

木質燃料の加工については、物質収率だけではなく投入 される製造エネルギー Xも課題 ${ }^{3)}$ があり、全体システムと して折り合いをつける評価が必要になる。Fig.7に、ペレッ 卜に到る過程を一覧する。生木の発熱量 Q。は製品ペレッ ト $Q_{f}$ にほとんど保存されるのはよいとしても、プロセス後 半の投入エネルギー、粉砕・乾燥・圧密化の外部エネルギー $X_{3} 、 X_{4} 、 X_{5} 、$ がかなり大きく、しばしば $Q_{f}$ の半分を超える ため、システムのエネルギー経済が問題になる。

半炭化のプロセスは Fig.7 のチップまでは同一であり、 圧密化の $X_{5}$ が加熱（あるいは加熱 + 圧密化）に入れ替わる 点が異なる。ゆえに半炭化においても、プロセス省エネル ギーは重要な課題である。

ペレット化

ペレット化の目的は、木材よりも燃焼制御が容易で、輸 送・貯蔵性に優れた燃料を得ることにある。木粉を圧密化 して径 5〜 $10 \mathrm{~mm}$ ・長さ $10 \sim 30 \mathrm{~mm}$ の円柱状の成型燃料 が市販されている。同様なもので約 4 倍の大きさの成型燃 料はブリケット ${ }^{4)}$ と呼ばれている。真比重は 1 を越してい るが輸送性を直接支配する容積密度は、約 $0.66 \mathrm{t} / \mathrm{m}^{3}$ である (空隙が影響)。発熱量は $18 \sim 20 \mathrm{MJ} / \mathrm{kg}$ であるから、灯油 $1 \mathrm{~L}$ はペレット $2 \mathrm{~kg}$ とほぼエネルギー的に等価である。

ペレット成型 ${ }^{5)} に は 、 一$ 見奇妙なことであるが、一定の 水分 $(15 \pm 3 \%)$ が望ましい。この值は、ほぼ木質の $2 / 3$ を 占めるセルロース等の理論吸湿值 $22 \%$ から導かれる值であ る(後述)。造粒機入り口で乾燥し過ぎていると、木粒が硬 く成型が困難になり圧縮動力が浪費され、水分 $5 \%$ 以下で はほとんど造粒不能になる。一方、造粒機出口で水分 $10 \%$ 以下にしないと造粒が崩れやすくなる。幸いにも、造粒機 内部の圧縮・摩擦による発熱で $100^{\circ} \mathrm{C}$ 以上になり水が蒸発 する。造粒機入り口水分が高過ぎると、その調製範囲から 外れてしまうので、水分調整は綱渡りになる。

ペレッターには、リングダイ、フラットダイなどが、ブ リケット用にはピストンプレス、スクリュープレスなどが
Table 4 Heating value per weight or volume

\begin{tabular}{|l|l|r|}
\hline & \multicolumn{1}{|c|}{$\mathrm{MJ} / \mathrm{kg}$} & \multicolumn{1}{|c|}{$\mathrm{MJ} / \mathrm{L}$} \\
\hline 木質 $($ 乾物 $)$ & 20 & $10 \pm 2$ \\
生木 (水分 45\%) & 10 & $5 \pm 1$ \\
\hline チップ (水分 $30 \%)$ & $11 \sim 14$ & $5 \sim 8$ \\
木質ペレット & $17 \sim 21$ & $7 \sim 13$ \\
$\mathrm{RDF}$ & $17 \sim 21$ & $8 \sim 10$ \\
$\mathrm{RPF}$ & $25 \sim 33$ & $13 \sim 20$ \\
\hline 灯油 & 44 & 37 \\
\hline
\end{tabular}

用いられるが、いずれも内圧が均一に伝わる必要があり、 大型化には苦労がある。

RDF（ごみ圧密化燃料）も原料が木質から都市ごみ ${ }^{6)} に$ 代わっただけで発熱量も同様（Table 4）である。だが、大 量・不均一形状 ·異物混入多い対象であり、前処理乾燥な どで発火の危険もあり、さらに木質ペレットと異なって清 浄な燃料と見なされないため、需要開拓に難点がある。ま た、RPF（廃プラスチック圧密化燃料）は石油なみの発熱 量を持つプラスチックを多量に含有するため、RDF の約 2 倍の発熱量（石炭なみ）となり、パルプ産業などで使用さ れているが、純粋なバイオマス燃料とはいい難い。

\section{1 半炭化物 I (熱圧加工物)}

半炭化域に入る前の乾燥域（Fig.1 の左上）において、微 加熱をやや長く続けると木材が軟化・変形し易くなること は古くから知られており、木材や竹材の熱加工に利用され ている。これは、木質の副成分であるへミセルロースが反 応性が高く、140 $180^{\circ} \mathrm{C}$ で水（あるいは水蒸気）存在下で 選択的に加水分解されて低分子化し、崩壊することによる。 (セルロース、リグニンは不変)

$$
\begin{aligned}
& -g|-x y-g|-x y-g \mid-\cdots+\mathrm{H}_{2} \mathrm{O} \\
& \Rightarrow-g|-x y-g|-\cdots x y, g \mid
\end{aligned}
$$

ヘミセルロースは、熱分解温度（>240 $\left.{ }^{\circ} \mathrm{C}\right)$ に達する前 から加水分解が始まる。そしてセルロースの糊材であった ヘミセルロースの崩壊により、セルロースの束は動きが自 由になり、木質軟化が起こる。木質軟化と並行して、へミ セルロースの構成成分であるマンノースやキシロースなど 可溶性糖類の抽出量増加 ${ }^{2)}$ が確認された。

一方、セルロース自体はこの温度域では崩壊せず、むし ろ乾燥の進行によりセルロースの $\mathrm{OH}$ 基への吸着水がはず れる。その結果、他のセルロース直鎖との接触・会合が促 進され、結晶化度が高まり、再配置による凝縮が進む。

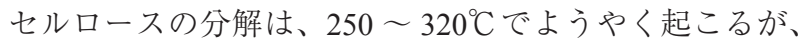
それは加水分解ではなく、レボグルコサンのような無水糖 （グルコース脱水物）の生成である。

つまり、へミセルロースの崩壊による木質流動化は、一 


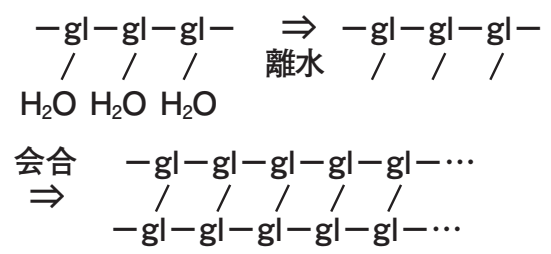

時的に木質の強度低下を引き起こすが、むしろセルロース 結束の強化のチャンスを与える。最近では、 $180^{\circ} \mathrm{C}$ 以上の昇 温処理によって木材を熱硬化樹脂のように整形・熱固定す る報告が相次いでいる。

特に、加熱時の加圧は生成物の強度増大をもたらす。他 方、リグニンの軟化による木材可塑化の同時進行も唱えら れているが、確実な証拠はない。

\section{バイオコークス}

木質の内部に扔けるへミセルロース分解による一時軟化 と $10 \sim 20 \mathrm{MPa}$ の加圧を併用すると、セルロース主鎖の会 合と結束を促し、真比重 1.32 に達し、木質全体の強度を著 しく高める。その結果、常温強度が石炭コークスを上回っ た製品が得られ、これらはバイオコークスと名付けられた。 化学組成的には木質とほとんど同じである。実際に一割程 度のコークス代替実証試験》)が行われた。原料は木質に限 らず、草本・茶滓などあらゆるリグノセルロースに適用可 能である。

\section{主炭化開始前の木質変性}

これらの木質変性は、へミセルロースの加水分解による 内部可塑化に基づくものと考えられる。加水分解を促すた めには、原料に一定の水分を持つことが必須である。

先に、セルロースの吸湿水（OH 基吸着による）が $22 \%$ 含水分に相当することを述べたが、これを超えた水分が木 質内部での真の自由水とみなされる。ここで、セルロース とへミセルロースとが同等の吸湿性を持ち、疎水性のリグ ニンは吸湿性ゼロと仮定すると、リグニン $30 \%$ の木質での 自由水確保に扔ける水分下限值は $15 \%$ ほどとなり、ペレッ 卜製造・木質軟化加工、などに扔ける原料の要求水分とほ ぼ一致する。バイオコークス製造プロセスはやや高温であ るため、セルロース吸着水の離脱が始まるので、要求水分 はいくらか少なめでよい。

木質の高温水蒸気による軟化加工は、 $180^{\circ} \mathrm{C}$ を越すと木 質の黒化をもたらす。だが、元素分析によるとまだ成分の 明瞭な变化は現れておらず、炭化の進行とはみなされない。 微量の脱水による 2 重結合 $(\mathrm{C}=\mathrm{C})$ の発生とセルロース主 鎖の接近、による可視光吸収の増大が黒化の原因であろう。

\section{2 半炭化物 II}

木質主成分のセルロースの熱分解は $240 \sim 250^{\circ} \mathrm{C}$ から開 始し、急激な重量減少と保持熱量の減少を引き起こす。半 炭化の目的の一つが保持熱量を損失せず重量減少を進める
ことにあるので、次の二つの分解ルートのうち、前者の分 解が好ましいことになる。

(1) セルロースの脱水。例 :

$$
\begin{aligned}
\left(\mathrm{C}_{6} \mathrm{H}_{10} \mathrm{O}_{5}\right) \mathrm{n} \Rightarrow & \mathrm{n}\left(6 \mathrm{C}+5 \mathrm{H}_{2} \mathrm{O}\right) \\
& \text { 炭素と水 }
\end{aligned}
$$

(2) セルロースから分解有機物の放出。例 :

$$
\begin{aligned}
\left(\mathrm{C}_{6} \mathrm{H}_{10} \mathrm{O}_{5}\right) \mathrm{n} \Rightarrow & \mathrm{nC}_{6} \mathrm{H}_{10} \mathrm{O}_{5} \\
& \text { レボグルコサン }
\end{aligned}
$$

普通のセルロース熱分解での残炭収率は $10 \%$ 以下と極め て少なく、反応(1)はあまり起きない。(2)の分解有機物の代 表は、構成するグルコース単位の無水物、レボグルコサン で、木タールの成分の 1 つである。だがレボグルコサンは 高温時に不安定な物質で、減圧加熱しない限り高い収率で 得ることはできない（ガス化・炭化分解する）。

残炭収率を上げる手段としては、加熱時に密閉・加圧し て発生有機物の滞留時間を延長する; リグニンなどでセル ロースをミクロな囲い込みに閉じ込める; 残炭発生率の高 い温度を精密に探索する; などが試みられている。

当初、半炭化物の本命として、熱分解 $\mathrm{S}$ 字曲線の途上で 止め、生成物を取り出して、原料エネルギーを温存し重量 が低下する可能性を探索した。だが、S 字曲線の勾配が急 なので $\mathrm{S}$ 字曲線の中点 $=300 \pm 50^{\circ} \mathrm{C}$ (1/2 炭化相当)におい て止めるのは困難であり、再現性あるデー夕を得ることに 成功していない。

だが、木質を常圧の油中で $350^{\circ} \mathrm{C} に$ 指定して熱分解し、 半炭化物収率 $59 \%$ を得た報告 ${ }^{8)}$ もあり、残炭分の増収条件 を見出す可能性はあるといえる。

副成分であるへミセルロースの半炭化 II 期の挙動につい て述べる。この時点までにすでに単糖（マンノース、キシ ロース、グルコース）への分解を終えて、さらなる熱分解 と熱重合（カラメル化）が進行し、セルロースより複雑な 幅広い熱分解期に入っている。そのため、セルロースより も多い残炭率を報告している例もある。しかし先に触れた ようにへミセルロースのモデル試料が確立しているわけで はないので、データの信頼性には今後の調査が必要である。

\section{3 半炭化物 III（プレ木炭）}

後期の半炭化（S 字曲線の中点より下）では、続く重量 減少が末期の木酢液や初期の夕ール放出を伴うので、原料 エネルギー分はかなり失われる過程になる。 $350^{\circ} \mathrm{C}$ 以上で は [C-C] 結合の開裂が始まり、リグニンの側鎖も分解し始 めるので、本格的な炭化の開始といえる。

近似的に云えば、半炭化物 I、IIでへミセルロース、セ ルロースが分解し終わり、半炭化物 III はリグニンが主体で ある、といえる。そして S 字曲線の終端の曲がり部分は、 リグニンの側鎖分解の時期である、といえよう。

半炭化物 IIIが右方の「木炭」と大きく異なる点は、多量 の揮発分を残存保有しており「火炎然燒できる木炭」であ 


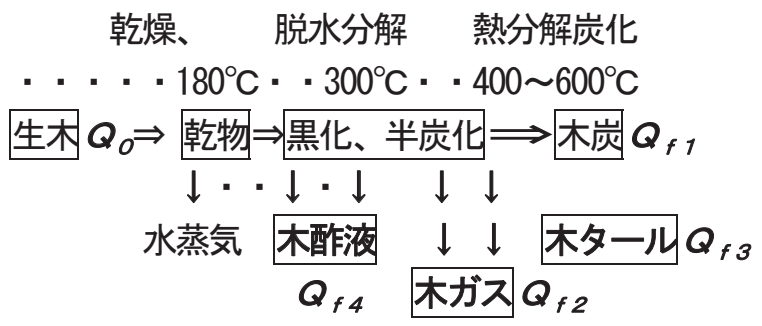

Fig.8 Energy distribution in woody coaking

ることである。もしエネルギーの確保と輸送・貯蔵性改善 だけを目指すとすれば、木炭化は不要で半炭化物 IIIに留め るべきものである。

炭化プロセスの特徴は、成分変化を伴うため、製品が多 岐にわたる（Fig.8）ことである。昇温とともに乾燥・加水 分解 $\left(\sim 180^{\circ} \mathrm{C}\right)$ 、部分脱水 $\left(300^{\circ} \mathrm{C}\right.$ 前後) と黑化・木酶液放出、 $400^{\circ} \mathrm{C}$ 以上に扔いて盛んにガス・タールなどを放出して木炭 化へと進む。

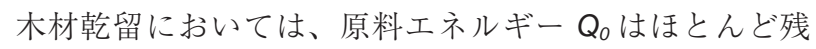
炭 $Q_{f 1} 、$ 木夕ール $Q_{f 3}$ 、木ガス $Q_{f 2}$ に移行する。木酢液は量 が多いが $80 \sim 90 \%$ が水であって $Q_{f 4}$ は僅かである。普通 の炭焼き条件では、1 次発生物の分布は、分解ガス $33 \%$ 、 木タール $22 \%$ 、残炭分 $40 \%$ 、くらいである。

半炭化の戦略は、残炭 $Q_{t 1}$ 、木夕ール $Q_{f 3}$ 、木ガス $Q_{t 2}$ の 熱量を半炭化物として回収して、エネルギー的増収をはか ることにある。

木炭に木タールを含浸させて、高熱量化をはかる提案 ${ }^{11}$ 9) が最近多く現れている。高圧で整形すると $1.1 \mathrm{~kg} / \mathrm{L}$ の比重 になり、32.6 MJ $/ \mathrm{kg}$ の高エネルギー密度になるという報告 もある。こうした試みに対して、半炭化システムは木ター ルを分離させないで高エネルギー密度化をはかり、あわせ てプロセスの省エネをはかる方向である、とみなすことが できる。

\section{6. まとめ}

バイオマス資源の有効利用には、原料から製品へのエネ ルギー収率の向上と、低エネルギー密度㧍よび高い空隙率 のため極度に悪かった輸送・貯蔵性を改善すること、の両 者が課題としてある。半炭化はその打開策として登場した ものであるが、その原理についてはようやく解明の緒につ いたばかりである。

半炭化物は、木質チップや゚ペットに対しては、重量当 たりのエネルギー密度では有利であるが、容積当たりのエ ネルギー密度では必ずしも優位ではない。圧密化によって 打開できるが、プロセス省エネにはまだ問題がある。

半炭化物は、木炭に対しては重量・容積いずれのエネル ギー密度も上回るし、プロセス省エネでもまさる。しかし
半炭化物は、エネルギー保持を揮発分の確保に求めている ため、炭火燃焼に対して火炎燃焼となり燃焼形式が木段と は異なる。燃料需要層がどのように開拓できるかは、今後 の問題である。

\section{参考文献}

1a) 本庄孝子：「未利用バイオマス資源化：BCDFへの道」燃料拀 よび然焼、 65 (1998) p.490-497.

1b) 本庄孝子、佐野寞：「新燃料・BCDF バイオマス資源化」31 回化学工学会大会、T301 (1998).

1c) 本庄ら：「BCDF 開発研究の道筋」20 回エ不資源学会論文集、 17-1 (2001) p.429-434.

1d) 本庄孝子ら:「バイオマスから新燃料·BCDF の開発」環境技術、 30-7 (2001) p. 510-515.

1e) 本庄孝子ら：「BCDF 化への基礎実験：圧力・温度による高工 ネルギー密度化」、日エネ学会 80 周年記念大会要旨集、(2002) p. 164-165.

1f) T.Honjo, H.Sano, T.Ida, M.Fucihata, "A new approach to advanced fuel from biomass: Semi Carbonized Biomass-pellets can increase both the energy \& energy yield", GHGT- 6, J4- 2(2002).

$1 \mathrm{~g})$ 本庄孝子ら：「新燃料 $\mathrm{BCDF}$ ：セルロース、オガクズ等の半炭 化圧密化」22 回工六資源学会論文集 (2003). p.389-394.

1h) 本庄孝子ら：「セルロースの加熱・圧密化による挙動とエネル ギー収率」日工学会・関西支部講演要旨集、3-40(2003).

1i）本庄孝子、佐野寛、井田民男：「ひまわりの半炭化ペレット化 燃料への可能性」エネルギー・コンファレンス論文集 (2004) p.479-482.

1j）本庄孝子佐野宽、井田民男：「半炭化ペレットの強度特性」エ 在資源学会論文集、(2004) p.139-142.

$1 \mathrm{k})$ 本庄ら :「新燃料 BCDF の可能性」日エネ誌、84(2005)p.142-148.

11) 本庄孝子ら:「木質バイオ固体燃料の高エネルギー密度化技術」 バイオマス科学会議、3-17 (2005).

2) 東原貴志：「水蒸気処理による圧縮木材の変形固定機構」、木 材工業、59-1 (2004) pp.2-7.

3) 佐野寛:「バイオマス資源からバイオ燃料へのエネルギー収 支」、高温学会誌、36-1 (2010) pp.4-5.

4) 日本エネルギー学会編；バイオマスハンドブック (2009) p.140, p.222, p.238.

5) 佐野寛：「バイオマス固体燃料：ペレット、半炭化物、木炭」 機械の研究、61-3 (2009) 373-378.

6a) 渡辺洋一：日工ネ誌、89 (2010) 498-507.

6b) 福田耕一：日エネ誌、89(2010) 522-527.

7) 井田民男ら：「鋳造コークス代替となる高硬度固形バイオ燃料 の量産機開発と実証」助成事業報告書（2009）平成 19 年度大 学発事業創出実用化研究開発事業 (NEDO).

8) N.Schwaiger ら：「油相熱分解産物」、米国化学工学会 2010 年 次大会 (2010), 452f.

9) 高橋ら：「木質バイオマスの炭化を利用した新発電燃料製造プ ロセス」第 41 回化学工学大会秋大会 (2009) AA103. 